\title{
Three Months of Regular Aerobic Exercise in Patients With Obesity Improve Systemic Subclinical Inflammation Without Major Influence on Blood Pressure and Endocrine Production of Subcutaneous Fat
}

\author{
P. TRACHTA ${ }^{1}$, J. DRÁPALOVÁ ${ }^{1}$, P. KAVÁLKOVÁ ${ }^{1}$, V. TOUŠKOVÁ ${ }^{1}$, A. CINKAJZLOVÁ ${ }^{1}$, \\ Z. LACINOVÁ ${ }^{1}$, M. MATOULEK ${ }^{1}$, T. ZELINKA ${ }^{1}$, J. WIDIMSKÝ Jr. ${ }^{1}$, M. MRÁZ ${ }^{1}$, \\ M. HALUZÍK ${ }^{1}$
}

${ }^{1}$ Third Department of Medicine, First Faculty of Medicine, Charles University and General University Hospital, Prague, Czech Republic

Received March 20, 2014

Accepted March 26, 2014

\section{Summary}

The aim of our study was to explore the effects of regular aerobic exercise on anthropometric, biochemical and hormonal parameters and mRNA expression of selected factors involved in metabolic regulations in subcutaneous adipose tissue of patients with obesity. Fifteen obese women with arterial hypertension underwent a three-month exercise program consisting of $30 \mathrm{~min}$ of aerobic exercise 3 times a week. Fifteen healthy lean women with no intervention served as a control group. Obese group underwent anthropometric measurements, blood sampling, subcutaneous adipose tissue (SCAT) biopsy and 24-h blood pressure monitoring at baseline and after three months of exercise, while control group was examined only once. At baseline, obese group had increased SCAT expression of proinflammatory cytokines and adipokines relative to control group. Three months of regular exercise improved anthropometric parameters, decreased CRP, blood glucose and HOMA-IR, while having no significant effect on lipid profile and blood pressure. Gene expressions in SCAT were not affected by physical activity with the exception of increased aquaporin-3 mRNA expression. We conclude that three months of regular exercise decrease systemic subclinical inflammation with only minor influence on the blood pressure and the endocrine function of subcutaneous fat.

\section{Key words}

Obesity - Physical activity - Adipose tissue - Proinflammatory factors

\section{Corresponding author}

M. Haluzik, Third Department of Medicine, First Faculty of Medicine, Charles University and General University Hospital, U Nemocnice 1, 12808 Prague 2, Czech Republic. Fax: + 420 224919780. E-mail: mhalu@lf1.cuni.cz

\section{Introduction}

The pathophysiology of various features of metabolic syndrome is complex and comprises multiple potential mechanisms including subclinical inflammation and disturbed endocrine function of adipose tissue (Ravussin and Smith 2002, Haffner 2003, Reaven et al. 2004). Adipose tissue, in particular the visceral fat, plays a pivotal role in this process by producing excessive amounts of proinflammatory and insulin resistanceinducing factors that contribute to the development of insulin resistance, arterial hypertension, subclinical inflammation and other pathologies clustered within metabolic syndrome (Mraz et al. 2011b, Trachta et al. 2014).

Adipose tissue of patients with obesity is characterized by increased infiltration by immunocompetent cells that, together with hypertrophic adipocytes, contribute to the proinflammatory milieu of obese fat $(\mathrm{Xu}$ et al. 2003, Neels and Olefsky 2006). Secreted factors include proinflammatory/ prothrombogenic cytokines that promote atherogenesis and contribute to the development of insulin resistance,

PHYSIOLOGICAL RESEARCH • ISSN 0862-8408 (print) • ISSN 1802-9973 (online)

(C) 2014 Institute of Physiology v.v.i., Academy of Sciences of the Czech Republic, Prague, Czech Republic

Fax +420 241062 164, e-mail: physres@biomed.cas.cz, www.biomed.cas.cz/physiolres 
arterial hypertension and atherosclerosis (Havel 2002, Mazurek et al. 2003). The endocrine production of adipose tissue and its anti/proinflammatory balance is regulated on multiple levels including its intensive interaction with circulating immunocompetent cells (Mraz et al. 2011a). Numerous epidemiological studies have shown that regular exercise is one of the most potent measures to protect against obesity, type 2 diabetes mellitus and long-term cardiovascular complications $(\mathrm{Hu}$ et al. 2004, Pi-Sunyer et al. 2007). While a single bout of acute exercise is accompanied by a short term proinflammatory response (Pedersen et al. 2001, Gleeson 2007), regular exercise evokes a long-term antiinflammatory effect (Kasapis and Thompson 2005, Timmerman et al. 2008). While some of the mechanisms behind the beneficial effects of regular exercise have been deciphered (Dunkley et al. 2012), the role of modulation of endocrine function of adipose tissue in this process remains only partially clarified, with some studies showing improved endocrine profile of fat with regular exercise while others failing to do so (Stefanyk and Dyck 2010, Lakhdar et al. 2013).

We hypothesized that regular physical activity could improve systemic subclinical inflammation and other obesity-related pathologies through the modulation of inflammatory profile of adipose tissue. To this end, we explored the effect of three months of regular exercise on anthropometric, biochemical and hormonal parameters, blood pressure and mRNA expression of adipokines, chemokines, cytokines and other relevant factors in subcutaneous adipose tissue.

\section{Methods}

\section{Study subjects}

Fifteen non-diabetic obese female patients with arterial hypertension (age 48.5 \pm 2.2 years, body mass index (BMI) $37.6 \pm 0.9 \mathrm{~kg} / \mathrm{m}^{2}$ ) were included in the study. The patients underwent a supervised three-month exercise program consisting of $30 \mathrm{~min}$ of aerobic exercise 3 times a week. The control group consisted of 15 healthy lean women (age $48.1 \pm 1.8$ years, BMI $23.7 \pm 0.6 \mathrm{~kg} / \mathrm{m}^{2}$ ).

Control subjects had no history of obesity and/or diabetes mellitus, arterial hypertension, or lipid metabolism disturbances and received no medication. Blood tests confirmed normal blood count, biochemical and hormonal parameters. In the obese group, 13 women were treated with antihypertensive medication, 2 had dyslipidemia treated with hypolipidemic agents, none of the patients had type 2 diabetes.

Written informed consent was signed by all participants before being enrolled into the study. The study was approved by the Human Ethics Review Board, First Faculty of Medicine and General University Hospital, Prague, Czech Republic.

Anthropometric examination, biochemical and hormonal determination, blood pressure measurements and tissue sampling

The obese group was examined at baseline and after three months of regular exercise, while the control group was examined only once. All subjects were measured and weighed, and their body mass index (BMI) was calculated. Percentage of total body fat was assessed by bioimpedance analysis (Multi-frequency Bodystat QuadScan 4000, Douglas, UK). In the obese group casual blood pressure (BP) values were obtained in the sitting position using a sphygmomanometer (LCD 301, Spirit Medical Co., Taiwan) and 24-h ambulatory blood pressure monitoring (ABPM) was performed using an oscillometric device (SpaceLabs 90207, SpaceLabs Medical, Redmond, WA, USA), which was set to measure the blood pressure every $20 \mathrm{~min}$ during the day (from $06: 00 \mathrm{~h}$ to $22: 00 \mathrm{~h}$ ) and every $30 \mathrm{~min}$ during the night (from 22:00 $\mathrm{h}$ to 06:00 $\mathrm{h}$ ). Casual blood pressure in the control group was measured only once at baseline. Blood samples for biochemical and hormonal measurements were withdrawn between $07: 00 \mathrm{~h}$ and 08:00 $\mathrm{h}$ after $12 \mathrm{~h}$ of overnight fasting. Blood samples were separated by centrifugation for $10 \mathrm{~min}$ at $1000 \times \mathrm{g}$ within $30 \mathrm{~min}$ from blood collection. Serum was subsequently stored in aliquots at $-80{ }^{\circ} \mathrm{C}$ until further analysis.

Samples of the subcutaneous adipose tissue (abdominal area) were obtained by subcutaneous needle aspiration biopsy. Approximately $100 \mathrm{mg}$ of adipose tissue was collected to $1 \mathrm{ml}$ of RNA stabilization Reagent (RNAlater, Qiagen, Germany) and stored at $-80{ }^{\circ} \mathrm{C}$ until further analysis.

\section{Hormonal and biochemical assays}

Serum concentrations of FABP-4, resistin, leptin and adiponectin were measured using a commercial ELISA kits (BioVendor, Modrice, Czech Republic) with a sensitivity of $0.1 \mathrm{ng} / \mathrm{ml}$ for FABP-4, $0.2 \mathrm{ng} / \mathrm{ml}$ for resistin, $0.12 \mathrm{ng} / \mathrm{ml}$ for leptin and $1.0 \mathrm{ng} / \mathrm{ml}$ for adiponectin. Serum C-reactive protein (CRP) levels were measured by high sensitive assay (Bender MedSystems, 
Vienna, Austria) with a sensitivity of $3 \mathrm{pg} / \mathrm{ml}$. Serum insulin concentrations were measured by commercial RIA kit (Cis Bio International, Gif-sur-Yvette, France) with a sensitivity of $2.0 \mu \mathrm{IU} / \mathrm{ml}$. The intra- and interassay variabilities of all kits were less than $5 \%$ and less than $10 \%$, respectively.

Biochemical parameters $\left(\mathrm{HbA}_{1 \mathrm{c}}\right.$, total $\mathrm{LDL}$ and HDL cholesterol, TAG, IA, glucose) were determined by standard laboratory methods in the Department of Biochemistry of General University Hospital, Prague.

\section{Determination of $m R N A$ expression}

Samples of subcutaneous adipose tissue were homogenized on MagNA Lyser Instrument with MagNA Lyser Green beads (Roche Diagnostics GmbH, Germany). Total RNA from homogenized tissue was extracted on MagNA Pure instrument using Magna Pure Compact RNA Isolation kit (tissue) (Roche Diagnostics GmbH, Germany). The RNA concentration was determined from absorbance at $260 \mathrm{~nm}$ on a NanoPhotometer (Implen, Munchen, Germany). Reverse transcription was performed using $0.25 \mu \mathrm{g}$ of total RNA to synthesize the first strand cDNA using the random primers as per the instructions of the HighCapacity cDNA Reverse Transcription Kit (Applied Biosystems, Foster City, CA, USA). Gene expression of FABP-4, CD68, adiponectin and its receptors, resistin, angiotensinogen (AGT), angiotensin-converting enzyme (ACE) and angiotensin receptor type 1 (AGTR1) was performed on a 7500 Real-Time PCR System using TaqMan ${ }^{\circledR}$ gene Expression Assays (Applied Biosystems, Foster City, CA, USA). Measurement of gene expression of other 44 genes was performed on ViiA7 Instrument using TaqMan Custom Array (Applied Biosystems, Foster City, CA, USA). A mix of TaqMan ${ }^{\circledR}$ Universal PCR Master Mix II, NO AmpErase ${ }^{\circledR}$ UNG (Applied Biosystems, Foster City, CA, USA), nuclease-free water (Fermentas Life Science, Lithuania) and specific TaqManGene expression Assays (Applied Biosystems, Foster City, CA) was used for reaction.

The increase in fluorescence was measured in real time and threshold cycle $(\mathrm{Ct})$ values were obtained. To compensate for variations in RNA amount and efficiency of reverse transcription, beta-2-microglobulin and HPCAL1 were used as endogenous reference and results were normalized to the mean of these values. The formula $2^{-\Delta \Delta C t}$ was used to calculate relative gene expression.

\section{Statistical analysis}

Statistical analysis was performed using SigmaStat software (SPSS Inc., Chicago, IL, USA). Results were expressed as means \pm SEM. Differences of gene expression, anthropometric, biochemical and hormonal parameters between obese and control group were evaluated using one-way ANOVA followed by Dunnett's Method as Multiple Comparison versus Control Group or Kruskal-Wallis One Way ANOVA on Ranks followed by Dunn's Method, as appropriate. Differences in parameters of obese group before and after three months of exercise were evaluated using paired t-test or Wilcoxon Signed Rank Test, as appropriate. The correlations between various parameters were estimated by Pearson product moment correlation test or Spearman rank order correlation test. Statistical significance was assigned to $\mathrm{P}<0.05$.

\section{Results}

Anthropometric, biochemical and hormonal characteristics of study subjects and its changes after three months of exercise

Anthropometric, biochemical and hormonal characteristics of both study groups are summarized in Table 1. At baseline, obese group had significantly higher body weight, BMI, body fat percentage, waist and hip circumference, fasting blood glucose, serum triglycerides, CRP, IA, insulin, leptin, FABP-4 and HOMA index compared to control group. Serum adiponectin and HDLcholesterol levels were significantly reduced in obese relative to control group.

Three months of regular exercise in obese group significantly reduced body weight, BMI, body fat percentage, waist and hip circumference, fasting blood glucose, CRP and HOMA index. Serum adiponectin, leptin, FABP-4 and insulin were not affected by exercise. Nor the casual or the $24-\mathrm{h}$ blood pressure values were significantly affected by the three months of exercise (Table 2).

mRNA expression of adipokines and inflammation and insulin pathway-related genes in subcutaneous adipose tissue

The summary of mRNA expressions of adipokines and inflammation and insulin pathway-related genes in subcutaneous adipose tissue of control and obese group before and after three months of regular exercise is shown in Table 3. 
Table 1. Anthropometric, biochemical and hormonal characteristics and blood pressure values of study subjects.

\begin{tabular}{|c|c|c|c|}
\hline & Controls & OB (before PA) & OB (after PA) \\
\hline Number (n) & 15 & 15 & 15 \\
\hline Dyslipidemia & 0 & 2 & 2 \\
\hline Diabetes mellitus & 0 & 0 & 0 \\
\hline Arterial hypertension & 0 & 15 & 15 \\
\hline Age (years) & $48.1 \pm 1.8$ & $48.5 \pm 2.2$ & $48.5 \pm 2.2$ \\
\hline Body mass index $\left(\mathrm{kg} / \mathrm{m}^{2}\right)$ & $23.7 \pm 0.6$ & $37.6 \pm 0.9 *$ & $35.4 \pm 0.8 * \dagger$ \\
\hline Body weight $(\mathrm{kg})$ & $67.5 \pm 2.3$ & $105.2 \pm 3.2 *$ & $99.2 \pm 3.0 * \dagger$ \\
\hline Body fat $(\%)$ & $29.0 \pm 1.8$ & $46.7 \pm 1.5 *$ & $42.6 \pm 2.0 * \dagger$ \\
\hline Waist circumference (cm) & $78.1 \pm 2.2$ & $108.4 \pm 2.2 *$ & $104.3 \pm 2.2 * \dagger$ \\
\hline Hip circumference $(\mathrm{cm})$ & $96.0 \pm 2.1$ & $125.5 \pm 2.2 *$ & $119.3 \pm 1.8 * \dagger$ \\
\hline Fasting blood glucose (mmol/l) & $4.81 \pm 0.09$ & $5.72 \pm 0.15^{*}$ & $5.32 \pm 0.12 * \dagger$ \\
\hline$H b A_{l c}(\% I F C C)$ & $3.79 \pm 0.08$ & $4.13 \pm 0.11$ & $4.01 \pm 0.09$ \\
\hline Triglycerides (mmol/l) & $0.96 \pm 0.10$ & $1.53 \pm 0.17 *$ & $1.44 \pm 0.18 *$ \\
\hline Cholesterol total ( $\mathrm{mmol} / \mathrm{l})$ & $5.17 \pm 0.27$ & $5.36 \pm 0.31$ & $5.45 \pm 0.25$ \\
\hline HDL-cholesterol (mmol/l) & $1.59 \pm 0.07$ & $1.34 \pm 0.06 *$ & $1.40 \pm 0.06$ \\
\hline LDL-cholesterol ( $\mathrm{mmol} / \mathrm{l})$ & $3.15 \pm 0.23$ & $3.34 \pm 0.28$ & $3.41 \pm 0.24$ \\
\hline Atherogenity index & $2.31 \pm 0.19$ & $3.11 \pm 0.25 *$ & $2.99 \pm 0.24$ \\
\hline HOMA-IR index & $3.35 \pm 0.17$ & $11.30 \pm 1.28^{*}$ & $9.11 \pm 0.99 * \dagger$ \\
\hline Adiponectin $(\mu g / m l)$ & $12.1 \pm 1.3$ & $8.4 \pm 1.3^{*}$ & $8.5 \pm 1.2 *$ \\
\hline Insulin $(m I U / l)$ & $15.6 \pm 0.7$ & $44.1 \pm 4.7^{*}$ & $38.0 \pm 3.4^{*}$ \\
\hline$F A B P-4(\mu g / m l)$ & $25.3 \pm 2.5$ & $39.3 \pm 3.9^{*}$ & $36.1 \pm 3.6^{*}$ \\
\hline Leptin $(n g / m l)$ & $13.5 \pm 2.0$ & $47.8 \pm 5.7^{*}$ & $40.4 \pm 4.1^{*}$ \\
\hline$h s C R P(u g / m l)$ & $0.20 \pm 0.06$ & $0.81 \pm 0.22^{*}$ & $0.56 \pm 0.12 * \dagger$ \\
\hline
\end{tabular}

Values are mean \pm SEM. Statistical significance is from One Way ANOVA vs. Control group and paired t-test or its non-parametric version vs. Obese after PA. ${ }^{*} \mathrm{p}<0.05$ vs. control group; ${ }^{\dagger} \mathrm{p}<0.05$ vs. Obese before PA. PA - physical activity; HOMA-IR - homeostasis model assessment - insulin resistance; FABP - fatty acid-binding protein.

Table 2. Blood pressure values of the study subjects.

\begin{tabular}{|c|c|c|c|c|}
\hline & & Controls & OB (before PA) & OB (after PA) \\
\hline \multirow{5}{*}{ Systolic blood pressure ( $\mathrm{mm} \mathrm{Hg}$ ) } & $24 h$ & $\mathrm{x}$ & $121.3 \pm 3.5$ & $119.2 \pm 2.9$ \\
\hline & Daytime & $\mathrm{x}$ & $124.33 \pm 4.1$ & $122.2 \pm 3.0$ \\
\hline & Nighttime & $\mathrm{x}$ & $113.1 \pm 3.6$ & $110.4 \pm 3.2$ \\
\hline & Casual & $129.3 \pm 3.2$ & $139.1 \pm 4.2$ & $132.3 \pm 3.7$ \\
\hline & $24 h$ & $\mathrm{x}$ & $71.8 \pm 3.0$ & $72.1 \pm 2.8$ \\
\hline \multirow{3}{*}{ Diastolic blood pressure ( $\mathrm{mm} \mathrm{Hg}$ ) } & Daytime & $\mathrm{x}$ & $75.9 \pm 3.4$ & $74.7 \pm 3.0$ \\
\hline & Nighttime & $\mathrm{x}$ & $66.4 \pm 3.0$ & $63.9 \pm 2.5$ \\
\hline & Casual & $78.7 \pm 1.1$ & $89.3 \pm 2.7 *$ & $86.9 \pm 3.4$ \\
\hline \multirow{4}{*}{ Heart rate (beats/min) } & $24 h$ & $\mathrm{x}$ & $73.5 \pm 1.9$ & $72.4 \pm 2.2$ \\
\hline & Daytime & $\mathrm{x}$ & $76.5 \pm 2.4$ & $74.1 \pm 2.2$ \\
\hline & Nighttime & $\mathrm{x}$ & $65.7 \pm 1.8$ & $67.4 \pm 2.5$ \\
\hline & Casual & $71.5 \pm 2.0$ & $76.8 \pm 4.0$ & $72.6 \pm 1.8$ \\
\hline
\end{tabular}

Values are mean \pm SEM. Statistical significance is from One Way ANOVA vs. Control group and paired t-test or its non-parametric version vs. Obese after PA. ${ }^{*} p<0.05$ vs. control group. 
At baseline, significant differences in mRNA expression were detected in 11 out of 53 studied genes in subcutaneous adipose tissue between obese and control group, respectively. mRNA expression in subcutaneous adipose tissue was undetectable in seven genes (SERPINA 12, IL-2, -3, -4, -12B, CCL-1, ITLN-1).

Increased expression of chemokines (CCL-2, -3, -4, -17), macrophage marker CD68, apelin, angiopoetin 1, IGF1R, CD-40-ligand, IL10 and STAT3 was found in subcutaneous fat of obese patients relative to control group, while mRNA expression of adiponectin in obese group was significantly decreased. mRNA expression of renin-angiotensin system-related genes did not differ between the groups.

The influence of physical activity on mRNA expression profile in obese patients with arterial hypertension

Three months of physical activity significantly increased mRNA expression of aquaporin-3, while no other studied genes were significantly affected by the exercise program.

\section{Discussion}

The most important finding of this study is that three months of regular aerobic exercise significantly decreased body weight and body fat, systemic subclinical inflammation and insulin resistance without having a major effect on endocrine function of adipose tissue, blood pressure or circulating lipid levels. These findings indicate that endocrine production of subcutaneous adipose tissue was not a major player in the improvement of systemic subclinical inflammation and insulin resistance.

Obesity is typically characterized not only by excessive amount of adipose tissue with adipocyte hypertrophy, but also by a marked alteration of its endocrine function and increased production of proinflammatory and insulin resistance-inducing factors (Bluher 2013). In our study, patients with obesity had markedly increased expression of chemotactic cytokines including $\mathrm{CC}$ chemokines 2, 3, 4 and 17 and macrophage marker CD68 compared to lean control subjects. This finding suggests increased proinflammatory milieu of adipose tissue in obese patients and higher infiltration of their adipose tissue with proinflammatory macrophages, which is in agreement with previously published data (Dahlman et al. 2005, Huber et al. 2008). Interestingly, obese patients had also increased mRNA expression of the anti-inflammatory cytokine IL-10 - one of the phenotypic markers of anti-inflammatory M2 macrophages (Turner et al. 2010), suggesting a complex influence of obesity on the adipose tissue immunocompetent cell content. Our data thus indicate the existence of a strong proinflammatory and chemoattractant state of subcutaneous adipose tissue for macrophages and other immunocompetent cells in obese non-diabetic patients with arterial hypertension.

Another interesting and possibly slightly surprising finding of our study is the observation that three months of regular exercise did not significantly change the expression of any up-regulated chemokines in SCAT. This data indicate a persistent proinflammatory and chemotactic profile in SCAT after the regular exercise intervention. The lack of effect of three months of regular physical activity on the inflammatory status of subcutaneous fat combined with improved systemic subclinical inflammation may have several explanations. Firstly, it has been demonstrated that subcutaneous adipose tissue, albeit comprising the largest fat depot, is not the most active player within different fat depots with respect to systemic metabolic effects (Bluher 2012). Both experimental and clinical studies have shown that the primary place of subclinical inflammation in patients with obesity both with or without type 2 diabetes mellitus is the visceral adipose tissue (Curat et al. 2006, Despres 2007). Although human studies did not, in contrast to experimental results, convincingly show that visceral fat is more proinflammatory than subcutaneous fat, they have clearly demonstrated that early body weight loss either by diet or exercise is mostly due to the decrease in visceral rather than subcutaneous fat (Imbeault et al. 1999, Dolinkova et al. 2008). In our study, significant loss of visceral fat was documented by a reduction of waist circumference suggesting that changes of endocrine function of adipose tissue could have been more pronounced in visceral that in subcutaneous fat. On the other hand, as we did not detect any major changes in the circulating levels of the most important systemic adipokines after the three-month exercise intervention, it is conceivable that the overall significance of the changes in the endocrine function of adipose tissue could have had only minor impact on the improvement of systemic subclinical inflammation and insulin resistance. 
Table 3. mRNA expression in SCAT of control group and obese patient with arterial hypertension before and after 3 months of physical activity.

\begin{tabular}{|c|c|c|c|c|}
\hline $\begin{array}{l}\text { Gene } \\
\text { symbol }\end{array}$ & Gene name & $\begin{array}{l}\text { Control } \\
(n=15)\end{array}$ & $\begin{array}{l}\text { Obese } \\
\text { (before PA) } \\
(n=15)\end{array}$ & $\begin{array}{l}\text { Obese } \\
(\text { after PA) } \\
(\mathbf{n}=\mathbf{1 5})\end{array}$ \\
\hline \multicolumn{5}{|c|}{ Adipokines and hormones } \\
\hline$A D I P O Q$ & Adiponectin & $1.026 \pm 0.062$ & $0.730 \pm 0.082 *$ & $0.734 \pm 0.075 *$ \\
\hline ADIPOR1 & Adiponectin receptor 1 & $1.044 \pm 0.086$ & $0.864 \pm 0.064$ & $0.982 \pm 0.118$ \\
\hline ADIPOR2 & Adiponectin receptor 2 & $1.041 \pm 0.076$ & $1.327 \pm 0.129$ & $1.212 \pm 0.117$ \\
\hline$A D M$ & Adrenomedullin & $1.066 \pm 0.122$ & $1.463 \pm 0.099$ & $1.645 \pm 0.157 *$ \\
\hline$A N G P T 1$ & Angiopoietin 1 & $1.049 \pm 0.086$ & $2.051 \pm 0.174 *$ & $1.826 \pm 0.199 *$ \\
\hline$A P L N$ & Apelin & $1.395 \pm 0.262$ & $3.312 \pm 0.673 *$ & $2.370 \pm 0.272$ \\
\hline ClQTNF1 & $\mathrm{C} 1 \mathrm{q}$ and tumor necrosis factor related protein 1 & $1.054 \pm 0.093$ & $1.217 \pm 0.151$ & $1.201 \pm 0.112$ \\
\hline DPP4 & Dipeptidyl-peptidase 4 & $1.058 \pm 0.092$ & $1.045 \pm 0.101$ & $1.057 \pm 0.113$ \\
\hline$F A B P-4$ & Fatty acid binding protein 4 & $1.067 \pm 0.114$ & $1.154 \pm 0.187$ & $1.210 \pm 0.220$ \\
\hline FAM132A & Family with sequence similarity 132 , member A & $1.042 \pm 0.080$ & $1.227 \pm 0.123$ & $1.099 \pm 0.129$ \\
\hline$K D R$ & $\begin{array}{l}\text { Kinase insert domain receptor (a type III } \\
\text { receptor tyrosine kinase) }\end{array}$ & $1.039 \pm 0.084$ & $1.082 \pm 0.080$ & $0.996 \pm 0.117$ \\
\hline$L C N 2$ & Lipocalin 2 & $2.473 \pm 0.851$ & $0.955 \pm 0.264$ & $1.825 \pm 1.178$ \\
\hline RARRES2 & $\begin{array}{l}\text { Retinoic acid receptor responder (tazarotene } \\
\text { induced) } 2\end{array}$ & $1.056 \pm 0.096$ & $1.084 \pm 0.082$ & $0.904 \pm 0.100$ \\
\hline$R B P 4$ & Retinol binding protein 4 , plasma & $1.069 \pm 0.107$ & $1.189 \pm 0.091$ & $0.986 \pm 0.135$ \\
\hline RETN & Resistin & $1.415 \pm 0.320$ & $1.685 \pm 0.261$ & $1.950 \pm 0.733$ \\
\hline$S A A 1 ; S A A 2$ & Serum amyloid A1;serum amyloid A2 & $1.152 \pm 0.162$ & $1.477 \pm 0.191$ & $1.360 \pm 0.148$ \\
\hline \multicolumn{5}{|l|}{ Aquaporines } \\
\hline$A Q P 1$ & Aquaporin 1 (Colton blood group) & $1.066 \pm 0.103$ & $1.321 \pm 0.132$ & $1.231 \pm 0.131$ \\
\hline$A Q P 3$ & Aquaporin 3 (Gill blood group) & $1.119 \pm 0.137$ & $1.472 \pm 0.141$ & $2.028 \pm 0.202 * \dagger$ \\
\hline$A Q P 7$ & Aquaporin 7 & $1.018 \pm 0.051$ & $0.945 \pm 0.048$ & $0.930 \pm 0.090$ \\
\hline$A Q P 9$ & Aquaporin 9 & $1.912 \pm 0.664$ & $1.120 \pm 0.169$ & $2.246 \pm 0.898$ \\
\hline \multicolumn{5}{|l|}{ Chemokines } \\
\hline$C C L 2$ & Chemokine (C-C motif) ligand 2 & $0.991 \pm 0.106$ & $2.567 \pm 0.308 *$ & $2.983 \pm 0.347 *$ \\
\hline CCL3 & Chemokine (C-C motif) ligand 3 & $1.881 \pm 0.656$ & $5.690 \pm 0.978 *$ & $4.633 \pm 0.832 *$ \\
\hline CCL4 & Chemokine (C-C motif) ligand 4 & $1.179 \pm 0.172$ & $2.257 \pm 0.397 *$ & $2.671 \pm 0.499 *$ \\
\hline CCL5 & Chemokine (C-C motif) ligand 5 & $1.544 \pm 0.419$ & $1.208 \pm 0.213$ & $1.826 \pm 0.467$ \\
\hline CCL17 & Chemokine (C-C motif) ligand 1 & $1.835 \pm 0.406$ & $4.364 \pm 0.806 *$ & $4.389 \pm 0.969 *$ \\
\hline CD68 & CD68 molecule & $1.137 \pm 0.153$ & $2.419 \pm 0.388 *$ & $2.570 \pm 0.454 *$ \\
\hline \multicolumn{5}{|l|}{ Cytokines } \\
\hline$I L 1 B$ & Interleukin 1, beta & $1.753 \pm 0.539$ & $0.880 \pm 0.173$ & $1.771 \pm 0.667$ \\
\hline IL6 & Interleukin 6 (interferon, beta 2) & $1.154 \pm 0.180$ & $1.461 \pm 0.253$ & $1.783 \pm 0.290$ \\
\hline IL 10 & Interleukin 10 & $1.442 \pm 0.415$ & $4.243 \pm 0.556 *$ & $4.310 \pm 0.494 *$ \\
\hline IL $12 A$ & $\begin{array}{l}\text { Interleukin 12A (natural killer cell stimulatory } \\
\text { factor } 1 \text {, cytotoxic lymphocyte maturation factor }\end{array}$ & $1.157 \pm 0.178$ & $1.414 \pm 0.242$ & $1.130 \pm 0.224$ \\
\hline
\end{tabular}




\begin{tabular}{|c|c|c|c|c|}
\hline \multicolumn{5}{|c|}{ Insulin signaling pathway } \\
\hline$I G F 1 R$ & Insulin-like growth factor 1 receptor & $1.051 \pm 0.097$ & $1.585 \pm 0.142 *$ & $1.388 \pm 0.179$ \\
\hline$I G F 2 R$ & Insulin-like growth factor 2 receptor & $1.043 \pm 0.084$ & $1.050 \pm 0.073$ & $1.222 \pm 0.099$ \\
\hline INSR & Insulin receptor & $1.048 \pm 0.095$ & $0.974 \pm 0.041$ & $0.884 \pm 0.071$ \\
\hline SHCl & $\begin{array}{l}\text { SHC (Src homology } 2 \text { domain containing) } \\
\text { transforming protein } 1\end{array}$ & $1.039 \pm 0.078$ & $1.514 \pm 0.169$ & $1.340 \pm 0.142$ \\
\hline SHC3 & $\begin{array}{l}\text { SHC (Src homology } 2 \text { domain containing) } \\
\text { transforming protein } 3\end{array}$ & $1.299 \pm 0.319$ & $1.121 \pm 0.206$ & $1.174 \pm 0.157$ \\
\hline$S L C 2 A 1$ & $\begin{array}{l}\text { Solute carrier family } 2 \text { (facilitated glucose } \\
\text { transporter), member } 1\end{array}$ & $1.076 \pm 0.113$ & $0.981 \pm 0.061$ & $1.127 \pm 0.121$ \\
\hline$S L C 2 A 3$ & $\begin{array}{l}\text { Solute carrier family } 2 \text { (facilitated glucose } \\
\text { transporter), member } 3\end{array}$ & $1.105 \pm 0.132$ & $1.194 \pm 0.080$ & $1.324 \pm 0.127$ \\
\hline \multicolumn{5}{|c|}{ Renin-angiotensin system } \\
\hline$A C E$ & A-converting enzyme & $1.039 \pm 0.079$ & $0.953 \pm 0.051$ & $0.931 \pm 0.0342$ \\
\hline$A G T$ & Angiotensinogen & $1.246 \pm 0.217$ & $0.837 \pm 0.105$ & $1.014 \pm 0.126$ \\
\hline AGTR1 & Angiotensin receptor 1 & $1.075 \pm 0.111$ & $0.922 \pm 0.063$ & $0.976 \pm 0.079$ \\
\hline \multicolumn{5}{|c|}{ Cell migration and other relevant genes } \\
\hline$C D 40$ & $\begin{array}{l}\text { CD } 40 \text { molecule, TNF receptor superfamily } \\
\text { member } 5\end{array}$ & $1.027 \pm 0.066$ & $1.293 \pm 0.105$ & $1.087 \pm 0.090$ \\
\hline$C D 40 L G$ & CD40 ligand & $1.589 \pm 0.397$ & $2.516 \pm 0.312$ & $3.400 \pm 0.727 *$ \\
\hline NAMPT & Nicotinamide phosphoribosyltransferase & $1.112 \pm 0.167$ & $0.895 \pm 0.078$ & $1.134 \pm 0.129$ \\
\hline STAT3 & $\begin{array}{l}\text { Signal transducer and activator of transcription } \\
3 \text { (acute-phase response factor) }\end{array}$ & $1.035 \pm 0.072$ & $1.579 \pm 0.177 *$ & $1.483 \pm 0.134 *$ \\
\hline STAT5A & $\begin{array}{l}\text { Signal transducer and activator of transcription } \\
5 \mathrm{~A}\end{array}$ & $1.033 \pm 0.073$ & $0.884 \pm 0.071$ & $0.832 \pm 0.089$ \\
\hline$V E G F C$ & Vascular endothelial growth factor $\mathrm{C}$ & $1.073 \pm 0.112$ & $1.355 \pm 0.105$ & $1.280 \pm 0.151$ \\
\hline
\end{tabular}

Values are mean \pm SEM. Statistical significance is from One Way ANOVA vs. Control group and paired t-test or its non-parametric version vs. Obese after PA. ${ }^{*} p<0.05$ vs. control group; ${ }^{\dagger} p<0.05$ vs. Obese before PA. PA - physical activity.

Interestingly, the only significant change in mRNA expression in subcutaneous fat after three months of exercise in our study was an increase in aquaporin-3 gene suggesting its possible connection to regular exercise. Aquaporins are a family of small, hydrophobic, integral membrane proteins expressed in multiple tissues and involved in water and glycerol transport, cell migration, neural signaling and numerous other processes (Rodriguez et al. 2011). Aquaporin-3 is strongly expressed in the basal layer of keratinocytes contributing to water transport and hydration of subcutaneous tissues (Agre 2006). Recent data have suggested its involvement in the regulation of cell proliferation through the regulation of glycerol transport. It is tempting to speculate that increased mRNA expression of aquaporin3 in the adipose tissue after physical activity could be connected to the changes of proliferative capacity of adipose tissue after regular exercise or to other exerciserelated regulatory processes (Guo et al. 2013). Nevertheless, since this is the first report possibly linking aquaporin-3 to exercise-induced changes in adipose tissue, our finding certainly requires further investigation.

Previous studies have suggested that increased expression of crucial components of the reninangiotensin-aldosterone system such as angiotensinconverting enzyme, angiotensinogen and angiotensin receptor 1 in adipose tissue may present another link between obesity and arterial hypertension (Engeli et al. 2003). In our study, all of the obese patients had arterial hypertension, yet we could not detect any significant differences in the mRNA expression of angiotensinconverting enzyme, angiotensinogen or angiotensin receptor 1 in their subcutaneous fat as compared to lean normotensive control subjects, nor any measurable effect 
of three months of regular exercise on these parameters. These findings are in line with the previous study by Giacchetti et al. who demonstrated increased angiotensinogen and angiotensin receptor 1 mRNA expression in visceral but not in subcutaneous fat of obese patients (Giacchetti et al. 2000). In our previous study on cardiac surgery patients, we did not detect any difference in mRNA expression of renin-angiotensinaldosterone components between epicardial and subcutaneous fat suggesting that their regulation might indeed be depot-specific (Roubicek et al. 2008). Collectively, these data do not support a connection between increased production of renin-angiotensinaldosterone components in subcutaneous fat and the presence of obesity and arterial hypertension.

Most of the long-term studies focused on the effects of regular exercise on circulating lipid levels have shown increased HDL-cholesterol and decreased triglyceride concentrations with changes being dependent on the frequency and duration of exercise (Schellenberg et al. 2013). In our study, only non-significant tendency towards these improvement were detected. The lack of a detectable effect of exercise could have been due to the fact that its frequency was relatively low, i.e. three times a week, and that the overall duration of the exercise program was only three months, while it was usually six months or more in most of other studies (Schwingshackl et al. 2013). Along the same line, we did not see any significant changes in blood pressure after three months of exercise. The lack of changes in blood pressure is most likely explainable by the fact that antihypertensive medication of our patients has been appropriately adjusted (mostly lowered) based on the changes of blood pressure throughout the study period. These finding show that, in contrast to changes in insulin sensitivity and systemic subclinical inflammation, longer duration of exercise or its higher frequency or intensity may be necessary to achieve significant improvements in blood pressure or circulating lipid levels.

In summary, our study has demonstrated that three months of regular exercise decreased systemic subclinical inflammation and improved insulin resistance with only minor influence on the endocrine function of subcutaneous fat and no significant effect on blood pressure and circulating lipid levels. These findings suggest that the changes of inflammatory status of subcutaneous fat probably did not contribute to positive metabolic and anti-inflammatory effects of regular exercise. An interesting and novel finding of increased aquaporin-3 mRNA expression in subcutaneous fat after the exercise program and its possible pathophysiological significance requires confirmation and clarification by further studies.

\section{Conflict of Interest}

There is no conflict of interest.

\section{Acknowledgements}

Supported by RVO-VFN 64165, SVV260019/2014 (Specific University Research Program) and project IGA MZ CR No. NT 13299-4.

\section{References}

AGRE P: The aquaporin water channels. Proc Am Thorac Soc 3: 5-13, 2006.

BLUHER M: Are there still healthy obese patients? Curr Opin Endocrinol Diabetes Obes 19: 341-346, 2012.

BLUHER M: Adipose tissue dysfunction contributes to obesity related metabolic diseases. Best Pract Res Clin Endocrinol Metab 27: 163-177, 2013.

CURAT CA, WEGNER V, SENGENES C, MIRANVILLE A, TONUS C, BUSSE R, BOULOUMIE A: Macrophages in human visceral adipose tissue: increased accumulation in obesity and a source of resistin and visfatin. Diabetologia 49: 744-747, 2006.

DAHLMAN I, KAAMAN M, OLSSON T, TAN GD, BICKERTON AS, WAHLEN K, ANDERSSON J, NORDSTROM EA, BLOMQVIST L, SJOGREN A, FORSGREN M, ATTERSAND A, ARNER P: A unique role of monocyte chemoattractant protein 1 among chemokines in adipose tissue of obese subjects. $J$ Clin Endocrinol Metab 90: 5834-5840, 2005.

DESPRES JP: Cardiovascular disease under the influence of excess visceral fat. Crit Pathw Cardiol 6: 51-59, 2007.

DOLINKOVA M, DOSTALOVA I, LACINOVA Z, MICHALSKY D, HALUZIKOVA D, MRAZ M, KASALICKY M, HALUZIK M: The endocrine profile of subcutaneous and visceral adipose tissue of obese patients. Mol Cell Endocrinol 291: 63-70, 2008. 
DUNKLEY AJ, CHARLES K, GRAY LJ, CAMOSSO-STEFINOVIC J, DAVIES MJ, KHUNTI K: Effectiveness of interventions for reducing diabetes and cardiovascular disease risk in people with metabolic syndrome: systematic review and mixed treatment comparison meta-analysis. Diabetes Obes Metab 14: 616-625, 2012.

ENGELI S, SCHLING P, GORZELNIAK K, BOSCHMANN M, JANKE J, AILHAUD G, TEBOUL M, MASSIERA F, SHARMA AM: The adipose-tissue renin-angiotensin-aldosterone system: role in the metabolic syndrome? Int J Biochem Cell Biol 35: 807-825, 2003.

GIACCHETTI G, FALOIA E, SARDU C, CAMILLONI MA, MARINIELlO B, GATTI C, GARRAPA GG, GUERRIERI M, MANTERO F: Gene expression of angiotensinogen in adipose tissue of obese patients. Int $J$ Obes Relat Metab Disord 24 (Suppl 2): S142-S143, 2000.

GLEESON M: Immune function in sport and exercise. J Appl Physiol (1985) 103: 693-699, 2007.

GUO L, CHEN H, LI Y, ZHOU Q, SUI Y: An aquaporin 3-notch1 axis in keratinocyte differentiation and inflammation. PLoS One 8: e80179, 2013.

HAFFNER SM: Insulin resistance, inflammation, and the prediabetic state. Am J Cardiol 92: 18J-26J, 2003.

HAVEL PJ: Control of energy homeostasis and insulin action by adipocyte hormones: leptin, acylation stimulating protein, and adiponectin. Curr Opin Lipidol 13: 51-59, 2002.

HU FB, WILLETT WC, LI T, STAMPFER MJ, COLDITZ GA, MANSON JE: Adiposity as compared with physical activity in predicting mortality among women. N Engl J Med 351: 2694-2703, 2004.

HUBER J, KIEFER FW, ZEYDA M, LUDVIK B, SILBERHUMER GR, PRAGER G, ZLABINGER GJ, STULNIG TM: CC chemokine and $\mathrm{CC}$ chemokine receptor profiles in visceral and subcutaneous adipose tissue are altered in human obesity. J Clin Endocrinol Metab 93: 3215-3221, 2008.

IMBEAULT P, LEMIEUX S, PRUD'HOMME D, TREMBLAY A, NADEAU A, DESPRES JP, MAURIEGE P: Relationship of visceral adipose tissue to metabolic risk factors for coronary heart disease: is there a contribution of subcutaneous fat cell hypertrophy? Metabolism 48: 355-362, 1999.

KASAPIS C, THOMPSON PD: The effects of physical activity on serum C-reactive protein and inflammatory markers: a systematic review. J Am Coll Cardiol 45: 1563-1569, 2005.

LAKHDAR N, BEN SAAD H, DENGUEZLI M, ZAOUALI M, ZBIDI A, TABKA Z, BOUASSIDA A: Effects of intense cycling training on plasma leptin and adiponectin and its relation to insulin resistance. Neuro Endocrinol Lett 34: 229-235, 2013.

MAZUREK T, ZHANG L, ZALEWSKI A, MANNION JD, DIEHL JT, ARAFAT H, SAROV-BLAT L, O'BRIEN S, KEIPER EA, JOHNSON AG, MARTIN J, GOLDSTEIN BJ, SHI Y: Human epicardial adipose tissue is a source of inflammatory mediators. Circulation 108: 2460-2466, 2003.

MRAZ M, LACINOVA Z, DRAPALOVA J, HALUZIKOVA D, HORINEK A, MATOULEK M, TRACHTA P, KAVALKOVA P, SVACINA S, HALUZIK M: The effect of very-low-calorie diet on mRNA expression of inflammation-related genes in subcutaneous adipose tissue and peripheral monocytes of obese patients with type 2 diabetes mellitus. J Clin Endocrinol Metab 96: E606-E613, 2011 a.

MRAZ M, LACINOVA Z, KAVALKOVA P, HALUZIKOVA D, TRACHTA P, DRAPALOVA J, HANUSOVA V, HALUZIK M: Serum concentrations of fibroblast growth factor 19 in patients with obesity and type 2 diabetes mellitus: the influence of acute hyperinsulinemia, very-low calorie diet and PPAR-alpha agonist treatment. Physiol Res 60: 627-636, 2011b.

NEELS JG, OLEFSKY JM: Inflamed fat: what starts the fire? J Clin Invest 116: 33-35, 2006.

PEDERSEN BK, STEENSBERG A, FISCHER C, KELLER C, OSTROWSKI K, SCHJERLING P: Exercise and cytokines with particular focus on muscle-derived IL-6. Exerc Immunol Rev 7: 18-31, 2001.

PI-SUNYER X, BLACKBURN G, BRANCATI FL, BRAY GA, BRIGHT R, CLARK JM, CURTIS JM, ESPELAND MA, FOREYT JP, GRAVES K, HAFFNER SM, HARRISON B, HILL JO, HORTON ES, JAKICIC J, JEFFERY RW, JOHNSON KC, KAHN S, KELLEY DE, KITABCHI AE, KNOWLER WC, LEWIS CE, MASCHAK-CAREY BJ, MONTGOMERY B, NATHAN DM, PATRICIO J, PETERS A, REDMON JB, REEVES RS, RYAN DH, SAFFORD M, VAN DORSTEN B, WADDEN TA, WAGENKNECHT L, WESCHE-THOBABEN J, WING RR, YANOVSKI SZ: Reduction in weight and cardiovascular disease risk factors in individuals with type 2 diabetes: one-year results of the look AHEAD trial. Diabetes Care 30: 1374$1383,2007$. 
RAVUSSIN E, SMITH SR: Increased fat intake, impaired fat oxidation, and failure of fat cell proliferation result in ectopic fat storage, insulin resistance, and type 2 diabetes mellitus. Ann NY Acad Sci 967: 363-378, 2002.

REAVEN G, ABBASI F, MCLAUGHLIN T: Obesity, insulin resistance, and cardiovascular disease. Recent Prog Horm Res 59: 207-223, 2004.

RODRIGUEZ A, CATALAN V, GOMEZ-AMBROSI J, FRUHBECK G: Aquaglyceroporins serve as metabolic gateways in adiposity and insulin resistance control. Cell Cycle 10: 1548-1556, 2011.

ROUBICEK T, DOLINKOVA M, BLAHA J, HALUZIKOVA D, BOSANSKA L, MRAZ M, KREMEN J, HALUZIK M: Increased angiotensinogen production in epicardial adipose tissue during cardiac surgery: possible role in a postoperative insulin resistance. Physiol Res 57: 911-917, 2008.

SCHELLENBERG ES, DRYDEN DM, VANDERMEER B, HA C, KOROWNYK C: Lifestyle interventions for patients with and at risk for type 2 diabetes: a systematic review and meta-analysis. Ann Intern Med 159: 543-551, 2013.

SCHWINGSHACKL L, DIAS S, STRASSER B, HOFFMANN G: Impact of different training modalities on anthropometric and metabolic characteristics in overweight/obese subjects: a systematic review and network meta-analysis. PLoS One 8: e82853, 2013.

STEFANYK LE, DYCK DJ: The interaction between adipokines, diet and exercise on muscle insulin sensitivity. Curr Opin Clin Nutr Metab Care 13: 255-259, 2010.

TIMMERMAN KL, FLYNN MG, COEN PM, MARKOFSKI MM, PENCE BD: Exercise training-induced lowering of inflammatory (CD14+CD16+) monocytes: a role in the anti-inflammatory influence of exercise? J Leukoc Biol 84: 1271-1278, 2008.

TRACHTA P, DOSTALOVA I, HALUZIKOVA D, KASALICKY M, KAVALKOVA P, DRAPALOVA J, URBANOVA M, LACINOVA Z, MRAZ M, HALUZIK M: Laparoscopic sleeve gastrectomy ameliorates mRNA expression of inflammation-related genes in subcutaneous adipose tissue but not in peripheral monocytes of obese patients. Mol Cell Endocrinol 383: 96-102, 2014.

TURNER JJ, FOXWELL KM, KANJI R, BRENNER C, WOOD S, FOXWELL BM, FELDMANN M: Investigation of nuclear factor-kappaB inhibitors and interleukin-10 as regulators of inflammatory signalling in human adipocytes. Clin Exp Immunol 162: 487-493, 2010.

XU H, BARNES GT, YANG Q, TAN G, YANG D, CHOU CJ, SOLE J, NICHOLS A, ROSS JS, TARTAGLIA LA, CHEN H: Chronic inflammation in fat plays a crucial role in the development of obesity-related insulin resistance. J Clin Invest 112: 1821-1830, 2003. 